\title{
Economic Analysis of Processing of Guava (Psydium guajava L.) in Uttar Pradesh State of India
}

\author{
S. H. Malik ${ }^{1} \&$ S. A. Saraf ${ }^{2}$ \\ ${ }^{1}$ Department of Agricultural Economics and Agribusiness Management, Sam Higginbotton Institute of \\ Agriculture, Technology and Sciences (SHIATS) [Formerly Allahabad agricultural Institute], Deemed \\ University, Allahabad, Uttar Pradesh, India \\ ${ }^{2}$ Department of Agricultural Economics, Faculty of Agriculture, Sher-e-Kashmir University of Agricultural \\ Sciences and Technology of Kashmir, Wadura Campus, Jammu and Kashmir, India \\ Correspondence: S. H. Malik, Department of Agricultural Economics and Agribusiness Management, Sam \\ Higginbottom Institute of Agriculture, Technology and Sciences (SHIATS) [Formerly Allahabad agricultural \\ Institute] Deemed University, Allahabad, Uttar Pradesh, India. E-mail: drsuheeb10@gmail.com
}

Received: February 27, 2013 Accepted: April 15, 2013 Online Published: May 15, 2013

doi:10.5539/jas.v5n6p44 URL: http://dx.doi.org/10.5539/jas.v5n6p44

\begin{abstract}
A study was conducted to analyse the economics of guava processing with the objectives of estimating benefit cost ratio, capacity utilization, cost of processing, price spread, marketing efficiency and constraints faced by guava processors in processing of guava in Allahabad district of Uttar Pradesh (U.P.) India. The processing of fresh guava was undertaken only by 10 units (processing firms) in the study area, so all the 10 units were evaluated for the present study. The processing units included cottage scale (03), small scale (05) and large scale (02). The study revealed that returns per rupee invested in cottage scale units, was calculated as 2.74 in making jelly and 2.99 in jam; for small scale units, it was 2.28 in jelly, 2.43 in jam and 1.89 in toffee; and for large scale units, the returns per rupee invested were 2.52 in the manufacture of jelly, 2.82 in jam and 2.01in toffee. As far as capacity utilization is concerned, the large scale units utilized $92.16 \%$ of installed capacity followed by cottage scale units with $86.73 \%$ and small scale with $79.89 \%$ capacity utilization, respectively. The cost of processing per quintal of guava was found to be Rs.176.60 (cottage scale), Rs.195.58 (small scale) and Rs.222.90 (large scale). Major problems faced by processors were non-availability of skilled labours, lack of capital, setting of guava products and degree of competition, etc. It could be concluded from the study that guava processing was an economically viable entrepreneurial activity and provided ample opportunities for employment generation particularly for the local youth, and also earning much required foreign exchange. This could be possible provided the government functionaries and concerned agencies take steps towards strengthening infrastructural support for a better marketing mechanism to be in place, and introduce export promotion schemes to boost the processing industry, given its competitive advantage. Efforts need to be made to encourage local unemployed youth to opt for guava processing as their livelihood source, by providing training and financial support to them.
\end{abstract}

Keywords: Guava processing, capacity utilization, price spread, marketing efficiency, benefit cost ratio

\section{Introduction}

Food processing industries are of enormous significance for the development of Indian economy, because of the vital linkages and synergies that it promote between the two pillars of the economy, namely; industry and agriculture. India is one of largest producers of raw materials for food processing industry. The industry itself is under developed in India as till now only less than $2 \%$ of fruits and vegetable production is processed compared with $30 \%$ in Thailand, $70 \%$ in Brazil, $78 \%$ in Philippines and $80 \%$ in Malaysia. The total wastage in all food sectors is as high as Rs. 50, 000 crores. Even if half of the wastage could be prevented, we would have enough calories to bring the nutritional status of our poor to above subsistence level. In this scenario, food processing becomes critical. This would move up surpluses at the farm level and ensure fair prices for the producers.

It is estimated that the growth potential of this sector is enormous, as it can bring immense benefits to the economy. It also has the potential to raise the agricultural yield, augment productivity, create employment and raise the standard of living of very large number of people throughout the country, especially in the rural areas. The food processing industry has been identified as a thrust area for development. 
Production of fruits and vegetables in India is about 70 million tons per year. It is estimated that nearly 35 to 40 per cent of the produce is wasted during picking, harvesting, packing, transportation, storage, marketing and consumption. Fruits and vegetables can earn 20 to 30 times foreign exchange per unit due to higher yield and better value than cereals in the international market. The development of fruits and vegetables based enterprises is gradually moving out of its rural confines into urban areas and from traditional agricultural enterprises to the corporate sector. This trend has led to the adoption of improved technology, greater commercialization and professionalism in the management of production and marketing. A number of export oriented units have potential for processing as its share in world trade foods and vegetables is lower than one per cent. The post-harvest handling, processing and management of the produce are necessary for avoiding losses. Value addition increases income and profit of the producers as well as entrepreneurs. The investment in the processing industry for producing processed agricultural products is remunerative. Therefore, keeping these facts in view, the present study; confined only to processing of Jam, Jelly and toffee, was designed with the following specific objectives:

1. To study the economics of guava processing.

2. To identify the problems faced by guava processors in processing and marketing of guava and its products, and suggest suitable remedial measures.

\section{Research Methodology}

The study was conducted in district Allahabad within the province of U.P., because this district has the reputation of growing best quality guava in the country. A complete list of all processing units was collected from Ministry of Food Processing Department, Lucknow. The study was conducted only for those processing units which were having FPO license. As per the FPO record there were 21 processing units in Allahabad district. Out of these 21 processing units, processing of fresh guava was undertaken only by 10 units. Therefore, all the 10 processing units were studied for the present study. The processing units were classified into three categories on the basis of the list obtained from the Ministry of Food Processing Department, Lucknow, i.e., cottage scale (03), small scale (05) and large scale (02). To get the desired information the data for the present study were collected from the selected processing units through personal interviews with the help of specially developed schedules. Simple statistical/ economic tools, as given below, were used for the estimation and interpretation of results.

\subsection{Producer's Share in Consumer's Rupee}

$$
\begin{gathered}
\text { Ps }=\frac{\text { Consumer's price }-(\text { marketing charges }+ \text { middle men's margin })}{\text { Consumer's price }} \mathrm{X} 100 \\
\text { Ps }=\frac{\text { Net amount received by producer }}{\text { Consumer's price }} \mathrm{X} 100
\end{gathered}
$$

\subsection{Marketing Cost}

It may be expressed as:

$$
\mathrm{C}=\mathrm{C}_{\mathrm{F}}+\mathrm{Cm}_{\mathrm{i}}+\mathrm{Cm}_{2}+\mathrm{Cm}_{3}+\ldots \ldots \ldots+\mathrm{C}_{\mathrm{mn}}
$$

Where, $\mathrm{C}=$ Total marketing cost of guava;

$\mathrm{C}_{\mathrm{F}}=$ Charges borne by the producer from the time the produce leaves the farm, till guava is sold to ultimate consumer; and $\mathrm{Cm}_{\mathrm{i}}=$ cost incurred by the $\mathrm{i}^{\text {th }}$ middlemen in the process of buying and selling the product.

\subsection{Marketing Margin of Middlemen}

This may be expressed by two ways

a. Absolute margin of $i^{\text {th }}$ middlemen

$$
[\text { Ami }]=\mathrm{P}_{\mathrm{R}} \mathrm{i}-\left[\mathrm{P}_{\mathrm{pi}}+\mathrm{C}_{\mathrm{mi}}\right]
$$

b. Percentage margin of $i^{\text {th }}$ middlemen $\left(\mathrm{P}_{\mathrm{mi}}\right)$

$$
\text { Pmi }=\frac{\text { PRi }-(\text { Ppi }+ \text { Cmi })}{\text { PRi }} \mathrm{X} 100
$$

Where, $\mathrm{P}_{\mathrm{Ri}}=$ total value of receipts per unit (Sale price);

$\mathrm{P}_{\mathrm{pi}}=$ purchase value of goods per unit (purchase price);

$\mathrm{C}_{\mathrm{mi}}=$ costs incurred on marketing per unit. 


\subsection{Marketing Efficiency}

The following method was used to calculate the marketing efficiency:

$$
\begin{gathered}
\text { Acharya's Method (MME) }=\frac{\text { Net price received by producer }}{\text { Total marketing cost }+ \text { total margin of intermediaries }} \\
\text { MME }=\frac{-\mathrm{FP}}{\mathrm{MC}+\mathrm{MM}}
\end{gathered}
$$

Where, $\mathrm{MME}=$ Modified measure of marketing efficiency;

$\mathrm{MC}=$ Total marketing cost;

$\mathrm{MM}=$ Net marketing margin;

$\mathrm{FP}=$ Price received by the grower;

$\mathrm{RP}=$ Price paid by the consumer.

2.5 Annual Capacity Utilization

$$
\text { Annual capacity utilization }=\frac{\text { Total quantity of Guava processed }}{\text { Total installed capacity }} \mathrm{X} 100
$$

\subsection{Benefit Cost Ratio}

It is the ratio of gross income and total cost of processing.

$$
\text { Benefit cost ratio }=\frac{\text { Gross income }}{\text { Total cost }}
$$

\subsection{Fixed and Variable Cost}

The fixed and variable costs have been worked out only for three months. The processing units of the study area would process guava only for 2.5 to 3 months (November to January) during a given year. This is because the processors preferred to process only the winter season crop and during the remaining period they processed other fruits.

\section{Results and Discussion}

Marketing channels of processed guava products followed by processing units:

\section{(a) Large scale}

(I) Producer - Preharvest contractor - Commission agent - Processing Unit -Commission \& Forwarding agent - Wholesaler - Retailer - Consumer.

(II) Producer - Commission agent - Processing unit - Commission \& Forwarding agent - Wholesaler Retailer - Consumer.

\section{(b) Small scale}

(III) Producer - Pre-harvest contractor - Commission agent - Processing unit - Commission \& forwarding agent - Wholesaler - Retailer - Consumer.

(IV) Producer - Commission agent - Processing unit - Commission \& forwarding agent - Wholesaler Retailer - Consumer.

\section{(c) Cottage scale}

(V) Producer - Pre-harvest contractor - Commissions agent - Processing unit - Commission \& forwarding agent - Consumers.

(VI) Producer - Commissions agent - Processing unit - Commission \& forwarding agent - Consumer.

\subsection{Marketing Channels of Processed Guava Products}

It can be observed from the above mentioned channels of processed guava products that the processors proved to be very important intermediaries in all the channels. All the possessors of the study area generally purchased the fresh guava from wholesaler /commission agent of Mundera market (mandi). In spite of many efforts by Government Center for Fruit Preservation and Training the processing of guava was not well adopted by the processors. Only about 3 percent of total fresh guava was being processed by the guava processors in Allahabad. As far as marketing of processed products is concerned, the processors sold the processed products in local market 
as well as in different distant markets. The processor moved the products through commission and forwarding agents dealing with processed products in different distant markets.

\subsection{Marketing Costs Incurred in the Marketing of Raw and Processed Guava Products}

\subsubsection{Cost Incurred by Growers}

The Table 1 indicated that the total marketing cost incurred by the producer was Rs. 148.90 per quintal in channel II, IV, and VI, which included, picking and assembling charges, grading, transportation, loading/ unloading and commission charges to commission agent, i.e., Rupees (Rs.) 13.67, 5.89, 62.31, 32.22, 5.45 and 29.36 per quintal, respectively.

Table 1. Marketing cost incurred by different intermediaries involved in the marketing of raw and processed guava products (Value in Rs. /Qtl.)

\begin{tabular}{|c|c|c|c|c|c|c|c|}
\hline $\begin{array}{l}\text { S. } \\
\text { No. }\end{array}$ & Particulars & $\begin{array}{c}\text { Channel } \\
\text { I }\end{array}$ & $\begin{array}{c}\text { Channel } \\
\text { II }\end{array}$ & $\begin{array}{c}\text { Channel } \\
\text { III }\end{array}$ & $\begin{array}{c}\text { Channel } \\
\text { IV }\end{array}$ & $\begin{array}{c}\text { Channel } \\
\text { V }\end{array}$ & $\begin{array}{c}\text { Channel } \\
\text { VI }\end{array}$ \\
\hline 1 & \multicolumn{7}{|c|}{ Charges paid by producer/pre-harvest contractors: } \\
\hline A & Picking and assembling charges & 12.34 & 13.67 & 12.34 & 13.67 & 12.34 & 13.67 \\
\hline B & Grading & 5.71 & 5.89 & 5.71 & 5.89 & 5.71 & 5.89 \\
\hline $\mathrm{C}$ & Packing and packaging material & 55.26 & 62.31 & 55.26 & 62.31 & 55.26 & 62.31 \\
\hline $\mathrm{D}$ & Transportation charges & 31.75 & 32.22 & 31.75 & 32.22 & 31.75 & 32.22 \\
\hline $\mathrm{E}$ & Loading/ unloading (Palledari) charges & 5.09 & 5.45 & 5.09 & 5.45 & 5.09 & 5.45 \\
\hline $\mathrm{F}$ & Commission charges & 27.88 & 29.36 & 27.88 & 29.36 & 27.88 & 29.36 \\
\hline & Total charges & 138.03 & 148.90 & 138.03 & 148.90 & 138.03 & 148.90 \\
\hline 2 & \multicolumn{7}{|c|}{ Charges paid by the commission agents: } \\
\hline A & Market (Mandi) tax @ 2\% & 10.20 & 10.20 & 10.20 & 10.20 & 10.20 & 10.20 \\
\hline B & Development charges@0.50\% & 2.55 & 2.55 & 2.55 & 2.55 & 2.55 & 2.55 \\
\hline $\mathrm{C}$ & Miscellaneous charges & 1.00 & 1.00 & 1.00 & 1.00 & 1.00 & 1.00 \\
\hline & Total charges & 13.75 & 13.75 & 13.75 & 13.75 & 13.75 & 13.75 \\
\hline 3 & \multicolumn{7}{|c|}{ Charges paid by processors: } \\
\hline A & $\begin{array}{l}\text { Commission to commission and } \\
\text { forwarding agent }(15-22 \%)\end{array}$ & 1836.69 & 836.69 & 2142.92 & 2142.92 & 2264.76 & 2264.76 \\
\hline & Total charges & 1836.69 & 1836.69 & 2142.92 & 2142.92 & 2264.76 & 2264.76 \\
\hline 4 & \multicolumn{7}{|c|}{ Charges paid by commission and forwarding agents: } \\
\hline a & Transportation charges & 128.30 & 128.30 & 55.20 & 55.20 & 34.00 & 34.00 \\
\hline $\mathrm{b}$ & Miscellaneous charges & 12.30 & 12.30 & 10.03 & 10.03 & 6.09 & 6.09 \\
\hline & total charges & 140.60 & 140.60 & 65.23 & 65.23 & 40.09 & 40.09 \\
\hline 5 & \multicolumn{7}{|c|}{ Charges paid by wholesalers: } \\
\hline $\mathrm{a}$ & Risk and maintenance & 131.67 & 131.67 & 131.67 & 131.67 & - & - \\
\hline $\mathrm{b}$ & Miscellaneous charges & 85.03 & 85.03 & 85.03 & 85.03 & - & - \\
\hline & Total charges & 216.70 & 216.70 & 216.70 & 216.70 & - & - \\
\hline 6 & Charges paid by retailer & & & & & & \\
\hline $\mathrm{a}$ & Transportation charges & 45.00 & 45.00 & 45.00 & 45.00 & - & - \\
\hline \multirow[t]{2}{*}{$\mathrm{b}$} & Risk and maintenance & 105.22 & 105.22 & 105.22 & 105.22 & - & - \\
\hline & Total charges & 150.22 & 150.22 & 150.22 & 150.22 & - & - \\
\hline
\end{tabular}




\subsubsection{Cost Incurred by Pre-Harvest Contractors}

It was observed from the Table 1 that the total cost incurred by the pre-harvest contractors was Rs. 138.03 in channel I, III and V which includes picking and assembling charges, grading, packing and packaging material, transportation, loading/ unloading and commission charges to commission agent (at mandi), i.e., Rs. 12.34, 5.71, $55.26,31.75,5.09$ and 27.88 per quintal, respectively.

\subsubsection{Cost Incurred by Commission Agent}

The Table 1 revealed that the charges paid by the commission agent in all the channels were Rs. 13.75 per quintal of guava which includes mandi tax @ 2\%, development charges @ 0.50\%, and miscellaneous charges at Re. 1.00 per quintal, i.e., Rs. 10.20, 2.55 and Re. 1.00 per quintal of guava, in the three channels, respectively.

\subsubsection{Charges Paid by the Processor}

The marketing cost incurred by the processors varied widely among the processing units, viz., large scale, small scale and cottage scale. The marketing cost incurred by the processors was basically commission based, which they were providing to commission and forwarding agents for marketing the processed guava products. The rate of commission provided by the large scale units was $15 \%$ of gross income, small scale at $18.50 \%$ and cottage scale at $22 \%$ of the gross income, i.e., Rs. 1836.69 per quintal in channel I and II, Rs., 2142.92 per quintal in channel III and IV, and Rs. 2264.76 per quintal in channel V and IV, respectively.

\subsubsection{Cost Incurred by the Commission and Forwarding Agent}

It was observed from the study that the commission agent played an important role in the marketing of processed guava products as they reached every nook and corner, where the firm itself could not, as it needed a lot of time and manpower. The total cost incurred by the commission and forwarding agent was found to be Rs. 140.60 per quintal in channel I and II, Rs. 65.23 per quintal in channel III and IV and Rs. 40.09 per quintal in channel V and VI, which included transportation charges at Rs. 128.30 per quintal and miscellaneous charges at Rs. 12.30 per quintal in channel I and II. In channel III and IV, transportation charges and miscellaneous charges were Rs. 55.20 and Rs. 10.03 per quintal, respectively while as in channel IV and VI, transportation and miscellaneous charges came to Rs. 34.00 and Rs. 6.09 per quintal, respectively.

\subsubsection{Cost Incurred by the Wholesalers}

The total marketing cost incurred by the wholesaler was found to be Rs. 216.70 per quintal in channel I, II, III and IV which included risk and maintenance cost at Rs. 131.67 per quintal and miscellaneous charges at Rs. 85.03 per quintal. In channel V and VI the wholesalers were not involved, because the cottage scale units were selling the processed guava products through commission agents as door to door services.

\subsubsection{Cost Incurred by Retailers}

The total cost incurred by the retailer was found at Rs. 150.22 per quintal in channel I, II, III and IV which included transportation charges at Rs. 45.00 per quintal and risk and maintenance cost as Rs. 105.22 per quintal.

\subsubsection{Capacity Utilization}

It can be observed from Table 2 that average capacity of 3 months was highest in large scale (2312.82 quintals), followed by small scale (150.62 quintals) and cottage scale (51.25 quintals). As far as the capacity utilization is concerned, the large scale units utilized $92.16 \%$ of their installed capacity followed by cottage scale with $86.73 \%$ and small scale units with $79.89 \%$, making aggregate percentage of $91.31 \%$.

Table 2. Processing of guava bye processing units of the study area

\begin{tabular}{ccccc}
\hline S. No. & $\begin{array}{c}\text { Category of } \\
\text { processing unit }\end{array}$ & $\begin{array}{c}\text { Average capacity } \\
\text { of } \mathbf{3} \text { months (Qtl.) }\end{array}$ & $\begin{array}{c}\text { Average quantity of } \\
\text { guava processed(Qti.) }\end{array}$ & Capacity Utilization (\%) \\
\hline 1. & Cottage scale & 51.25 & 44.45 & 86.73 \\
2. & Small scale & 150.62 & 120.33 & 79.89 \\
3. & Large scale & 2312.82 & 2131.52 & 92.16 \\
4. & Aggregate & 838.23 & 765.43 & 91.31
\end{tabular}

* The average annual capacity of cottage scale units in the study area was $20.50 \mathrm{M} \mathrm{T}$.

* The average annual capacity of small scale units in the study area was 60.25 M T.

* The average annual capacity of large scale unit in the study area was 925.13 M T. 


\subsection{Cost of Processing}

\subsubsection{Cottage Scale Processing Units}

To work out the cost of guava processing, various fixed and variable costs were calculated for each category of units surveyed and to arrive at the cost of processing per quintal weighted average were considered.

Table 3 reveals that for the processing of guava, total fixed cost incurred by cottage scale processors accounted to only Rs. 4640.96 (i.e., 59.12 percent of the total cost). This included rental value of land, depreciation on building, depreciation on equipments, wages to permanent labours, and interest on fixed capital, i.e., 4.45, 2.48, 1.04, 39.81, and 11.33 per cent, respectively, of the total cost. Whereas the total variable cost incurred was Rs.3208.81 which included electricity charges, administrative charges, repair and maintenance, license fee to FPO, wages to casual labours, commission to commission agents (in the market), other charges (advertising and telephone), and interest on working capital, i.e., $1.83,1.91,1.11,0.08,10.19,13.99,8.04$, and 3.72 per cent, respectively, of the total cost. Thus, the total fixed plus variable cost for cottage scale units was Rs. 7849.77. Average quantity of guava processed by cottage scale units was 44.45 quintals. Cost of processing per quintal of guava was estimated to be Rs. 176.60 .

Table 3. Cost of processing of guava by cottage, small and large scale units (Value in rupees)

\begin{tabular}{|c|c|c|c|c|c|c|c|}
\hline \multirow{2}{*}{$\begin{array}{l}\text { S. } \\
\text { No. }\end{array}$} & \multirow{2}{*}{ Items } & \multicolumn{2}{|c|}{ Cottage Unit } & \multicolumn{2}{|c|}{ Small Unit } & \multicolumn{2}{|c|}{ Large Unit } \\
\hline & & Amount & $\%$ & Amount & $\%$ & Amount & $\%$ \\
\hline A. & Fixed Cost: & & & & & & \\
\hline I & Rental value of land & 349.00 & $(4.45)$ & 499.99 & $(2.12)$ & 1687.50 & $(0.36)$ \\
\hline II & Depreciation on Building@5\% & 195.05 & $(2.48)$ & 900.89 & $(3.83)$ & 1604.17 & $(0.34)$ \\
\hline III & $\begin{array}{l}\text { Depreciation on Equipments @ } \\
5 \%\end{array}$ & 82.01 & $(1.04)$ & 1835.48 & $(7.80)$ & 10937.50 & $(2.30)$ \\
\hline IV & $\begin{array}{l}\text { Depreciation on } \\
\text { transportation @ } 5 \%\end{array}$ & - & - & 658.82 & $(2.80)$ & 1573.76 & $(0.33)$ \\
\hline $\mathrm{V}$ & Insurance Premium & - & - & 450.00 & $(1.91)$ & 5499.99 & $(1.16)$ \\
\hline VI & Wages to permanent labours & 3124.99 & $(39.81)$ & 3525.17 & $(14.98)$ & 126249.99 & $(26.57)$ \\
\hline VII & Interest on fixed capital @ 10\% & 888.92 & (11.33) & 9018.50 & $(38.32)$ & 112865.11 & $(23.75)$ \\
\hline \multicolumn{2}{|c|}{ Total fixed cost } & 4640.96 & $(59.12)$ & 16888.85 & $(71.76)$ & 260418.02 & $(54.81)$ \\
\hline B. & Variable cost & & & & & & \\
\hline I & Electricity charges & 143.90 & $(1.83)$ & 505.33 & $(2.15)$ & 15000.00 & $(3.16)$ \\
\hline II & Administrative charges & 150.00 & $(1.91)$ & 324.99 & $(1.38)$ & 3499.99 & $(0.74)$ \\
\hline III & Repair and Maintenance & 87.51 & $(1.11)$ & 637.56 & $(2.71)$ & 23749.99 & $(5.00)$ \\
\hline IV & License fee & 6.44 & $(0.08)$ & 18.81 & $(0.08)$ & 1291.75 & $(0.27)$ \\
\hline $\mathrm{V}$ & Wages to casual labours & 800.01 & $(10.19)$ & 707.50 & $(3.01)$ & 87499.99 & $(18.41)$ \\
\hline VI & $\begin{array}{l}\text { Commission to commission } \\
\text { agent (In Mandi) }\end{array}$ & 1097.91 & $(13.99$ & 2972.15 & $(12.62)$ & 52648.54 & $(11.08)$ \\
\hline VII & Other charges (Adv. Tel) & 631.33 & $(8.04)$ & 874.99 & $(3.72)$ & 11499.99 & $(2.42)$ \\
\hline \multirow[t]{5}{*}{ VIII } & $\begin{array}{l}\text { Working cost. } \\
\text { Interest on working capital @ } \\
10 \% \text {. }\end{array}$ & $\begin{array}{l}2917.1 \\
291.71\end{array}$ & $\begin{array}{c}- \\
(3.72)\end{array}$ & $\begin{array}{c}6041.33 \\
604.13\end{array}$ & $\begin{array}{c}- \\
(2.57)\end{array}$ & $\begin{array}{c}195190.25 \\
19519.02\end{array}$ & $\begin{array}{c}- \\
(4.11)\end{array}$ \\
\hline & Total working cost & 3208.81 & $(40.88)$ & 6645.46 & $(28.24)$ & 214709.27 & $(45.19)$ \\
\hline & Total cost (FC + VC) & 7849.77 & $(100)$ & 23534.31 & $(100)$ & 475127.29 & $(100)$ \\
\hline & Average guava processed (Qtl.) & 44.45 & & 120.33 & & 2131.52 & \\
\hline & Cost of processing/q. of guava & 176.60 & & 195.58 & & 222.90 & \\
\hline
\end{tabular}




\subsubsection{Small Scale Processing Units}

Table 3 indicated that the total cost incurred by small scale processing units was Rs. 23534.31, which included fixed cost of Rs. 16888.85 and working cost of Rs. 6645.46.The fixed cost included rental value of land, depreciation on building, equipments and owned transport, insurance premium, wages to permanent labourers and interest on fixed capital, i.e., 2.12, 3.83, 7.80, 2.80, 1.91, 14.98 and 38.32 per cent, respectively. The total fixed cost was $71.76 \%$ of the total cost. The working cost included electricity charges, administrative charges, repair and maintenance, license fee to FPO, wages to casual labourers, commission to commission agent (in mandi), other charges (advertising and telephone) and interest on working capital, i.e., 2.15, 1.38, 2.71, 0.08, 3.01, 12.62, 3.72, and 2.57 per cent respectively. The total working cost was $28.24 \%$ of the total cost. The average quantity of guava processed by small scale was 120.33 quintals. Thus, the cost of processing per quintal of guava incurred by small scale processing units was Rs. 195.58 .

\subsubsection{Large Scale Processing Unit}

Table 3 revealed that for processing of guava, total fixed cost incurred by large scale processors was estimated as Rs. 260418.02 (i.e., 54.81 per cent of the total cost), which included rented value of land, depreciation on building, equipments and owned transportation, insurance premium, wages to permanent labourers and interest on working capital, i.e., $0.36,0.34,2.30,0.33,1.16,26.57$ and 23.75 per cent of the total cost, respectively. Whereas, the total variable cost incurred was Rs. 214709.27 which included electricity charges, administrative charges, license fee to FPO, wages to casual labourers, commission to commission agent (in the market). Other charges (advertising and telephone) and interest on working capital accounted for 3.16, 0.74, 5.00, 0.27, 18.41, 11.08, 2.42, and 4.11 per cent, respectively of the total cost. Thus, the total fixed and variable cost accounted for the large scale units was Rs. 475127.29. The average quantity of guava processed by large scale units was 2131.52 quintals and the cost of processing per quintal of guava was estimated as Rs. 222.90 .

\subsection{Costs and Returns from Processing of Jam and Jelly by Cottage Scale}

\subsubsection{Costs and Margins in the Processing of Jelly}

The Table 4 revealed that the costs incurred by cottage scale units in the processing of one quintal of guava for making jelly were Rs.3967.83, which included cost of processing, cost of raw material, transportation charges, fuel charges, loss during processing, ingredient cost, packing and labeling, miscellaneous charges, and interest on working capital, i.e., $4.45,12.85,0.50,2.15,0.25,31.76,1.31,37.38,0.25$ and 9.09 per cent, of the total cost, respectively. The highest share (37.38\% of total cost) was accounted for the packing and labeling charges. From one quintal of guava, 1.13 quintals of jelly were recovered, after value addition the net margin received by the processors in selling 1.13 quintals was Rs.6908.42; per kg net margin was Rs. 61.14.

\subsubsection{Costs and Margins in the Processing of Jam}

It can be observed from the Table 4 that the cost incurred by cottage scale units in the processing of one quintal of guava for making Jam was Rs. 3249.53. The Jam is the by-product of Jelly, after making the jelly, remaining pulp was used for making the jam. Thus, on processing one quintal of raw guava, 1.13 quintal of jelly and 1.05 quintal of jam could be recovered. The cost which involves in making jam includes, cost of processing fuel charges, loss during processing, ingredient cost, packing and labeling charges, miscellaneous charges and interest on working capital were $5.43,2.63,0.22,38.77,1.23,42.41,0.22$, and $9.09 \%$ of the total cost, respectively. The highest share ( $42.41 \%$ of total cost) was accounted for packing and labeling charges, after value addition the net margin received by the processor in selling 1.05 quintals were Rs. 6462.97 and the per kg net margin were Rs. 61.55.

\subsection{Costs and Margins in the Processing of Jelly, Jam and Toffee by Small Scale Units}

\subsubsection{Costs and Margins in the Processing of Jelly}

The Table 5 reveals that the cost incurred by small scale units in the processing of one quintal of guava for making jelly was Rs. 4106.66, which included cost of processing, cost of raw material, transportation charges, fuel charges, loss during processing, cost of ingredients (Sugar, citric acid) packing and labeling charges, miscellaneous charges and interest on working capital, i.e., 4.76, 12.42, 0.59, 2.11, 0.28, 30.68, 1.27, 38.50, 0.29 and 9.09 per cent of the total cost, respectively. On processing one quintal of raw guava 1.15 quintal of jelly were recovered. After value addition the net margin received by the processor in selling 1.15 quintal of jelly was Rs. 5237.09 , whereas per $\mathrm{kg}$ net margin was Rs. 45.54. 
Table 4. Costs and margins in processing of Jam and Jelly by cottage units

\begin{tabular}{|c|c|c|c|c|c|}
\hline \multirow[b]{2}{*}{ S. No. } & \multirow[b]{2}{*}{ Particulars } & \multicolumn{2}{|c|}{ Jelly } & \multicolumn{2}{|c|}{ Jam } \\
\hline & & $\begin{array}{l}\text { Amount } \\
\text { (Rs./Qtl.) }\end{array}$ & $\%$ & $\begin{array}{l}\text { Amount } \\
\text { (Rs./Qtl.) }\end{array}$ & $\%$ \\
\hline 2 & Cost of processing & 176.60 & 4.45 & 176.60 & 5.43 \\
\hline 3 & Cost of raw material & 510.00 & 12.85 & - & \\
\hline 4 & Transportation charges & 20.00 & 0.50 & - & \\
\hline 5 & Fuel charges/power input & 85.40 & 2.15 & 85.40 & 2.63 \\
\hline \multirow[t]{2}{*}{6} & Loss during processing & 10.00 & 0.25 & 7.00 & 0.22 \\
\hline & Ingredient cost & & & & \\
\hline \multirow[t]{2}{*}{7} & (a) $\quad$ Sugar @ 70 kg/q. & 1260.00 & 31.76 & 1260.00 & 38.77 \\
\hline & Citric acid@200,153 gm/q. & 52.00 & 1.31 & 40.00 & 1.23 \\
\hline 8 & Packing and labelling charges & 1483.12 & 37.38 & 1378.12 & 42.41 \\
\hline 9 & Miscellaneous charges & 10.00 & 0.25 & 7.00 & 0.22 \\
\hline \multirow{2}{*}{10} & Interest on working capital @ 10\% & 360.71 & 9.09 & 295.41 & 9.09 \\
\hline & Total working cost & 3967.83 & 100 & 3249.53 & 100 \\
\hline 11 & Total quantity ready from one quintal Of guava & 1.13 & & 1.05 & \\
\hline 12 & Total returns from one quintal of processed guava & 10876.25 & & 9712.50 & \\
\hline 13 & $\begin{array}{l}\text { Net margin from one quintal of processed guava (excluding } \\
\text { marketing cost) }\end{array}$ & 6908.42 & & 6462.97 & \\
\hline 14 & Cost $/ \mathrm{kg}$ of processed products & 35.11 & & 30.95 & \\
\hline 15 & Selling price/kg & 96.25 & & 92.50 & \\
\hline 16 & Net margins/kg (excluding marketing cost) & 61.14 & & 61.55 & \\
\hline
\end{tabular}

Quantity of guava processed to jam \& jelly - 44.45 Qtl.

Table 5. Costs and margins in the processing of jelly, Jam and toffee by small scale units

\begin{tabular}{|c|c|c|c|c|c|c|c|}
\hline \multirow[b]{2}{*}{$\begin{array}{l}\text { S. } \\
\text { No. }\end{array}$} & \multirow[b]{2}{*}{ Particulars } & \multicolumn{2}{|c|}{ Jelly } & \multicolumn{2}{|c|}{ Jam } & \multicolumn{2}{|c|}{ Toffee } \\
\hline & & $\begin{array}{c}\text { Amount } \\
\text { (Rs. } \\
\text { Qtl.) }\end{array}$ & $\%$ & $\begin{array}{c}\text { Amount } \\
\text { (Rs. } \\
\text { Qtl.) }\end{array}$ & $\%$ & $\begin{array}{c}\text { Amount } \\
\text { (Rs. } \\
\text { Qtl.) }\end{array}$ & $\%$ \\
\hline 1 & Cost of processing & 195.58 & $(4.76)$ & 195.58 & (5.79) & 195.58 & (2.49) \\
\hline 2 & Cost of raw material & 510.00 & (12.42) & - & & 510.00 & $(6.48)$ \\
\hline 3 & Transportation charges & 24.22 & $(0.59)$ & - & & 24.22 & $(0.31)$ \\
\hline 4 & Fuel charges/powder input & 86.78 & (2.11) & 86.78 & $(2.57)$ & 86.78 & $(1.10)$ \\
\hline 5 & $\begin{array}{l}\text { Loss during processing } \\
\text { Ingredient cost }\end{array}$ & 11.50 & $(0.28)$ & 9.50 & $(0.28)$ & 11.50 & $(0.15)$ \\
\hline & (a) Sugar @ $70 \mathrm{~kg} / \mathrm{q}$. & 1260.00 & (30.68) & 1260.00 & (37.33) & 1260.00 & $(16.02)$ \\
\hline 6 & (b) Citric acid @ 200, 190 gm/q. & 52.00 & $(1.27)$ & 52.00 & $(1.54)$ & 49.40 & $(0.63)$ \\
\hline o & (c) Glucose @ 10 kg/q. & - & & - & & 800.00 & $(10.17)$ \\
\hline & (d) Skimmed milk (@15kg/q. & - & & - & & 900.00 & (11.44) \\
\hline & (e) Butter $@ 6$ kg/q. & - & & - & & 600.00 & (7.63) \\
\hline 7 & Packing and labelling charges & 1581.25 & $(38.50)$ & 1457.50 & (43.18) & 2700.00 & (34.33) \\
\hline 8 & Miscellaneous charges & 12.00 & $(0.29)$ & 7.50 & $(0.22)$ & 12.00 & $(0.15)$ \\
\hline 9 & Interest on working capital @ 10\% & 373.33 & $(9.09)$ & 306.89 & (9.09) & 714.95 & $(9.09)$ \\
\hline 10 & Total working cost & 4106.66 & (100) & 3375.75 & (100) & 7864.43 & (100) \\
\hline 11 & $\begin{array}{l}\text { Total quantity ready from one quintal of } \\
\text { guava }\end{array}$ & 1.15 & & 1.06 & & 1.35 & \\
\hline 12 & $\begin{array}{l}\text { Total returns from one quintal of processed } \\
\text { guava }\end{array}$ & 9343.75 & & 8215.00 & & 14850.00 & \\
\hline 13 & $\begin{array}{l}\text { Net margin from one quintal of processed } \\
\text { guava (excluding marketing cost) }\end{array}$ & 5237.09 & & 4839.25 & & 6985.57 & \\
\hline 14 & Cost $/ \mathrm{kg}$ of processed products & 35.70 & & 31.85 & & 58.25 & \\
\hline 15 & Selling price/kg & 81.25 & & 77.50 & & 110.00 & \\
\hline 16 & Net margins/kg (excluding marketing cost) & 45.54 & & 45.65 & & 51.75 & \\
\hline
\end{tabular}

Quantity of guava processed into jelly \& toffee [Jelly 87.12 Qt1.] [Toffee 33.21 Qt1.]. 


\subsubsection{Costs and Margins in the Processing of Jam}

It can be observed from the Table 5 that the cost incurred by small scale units in the processing of one quintal of raw guava for making Jam was Rs. 3375.75, which includes cost of processing, fuel charges, loss during processing, ingredient cost (sugar, citric acid), packing and labeling charges, miscellaneous charge and interest on working capital, i.e., 5.79, 2.57, 0.28, 37.33, 1.54., 43.18, 0.22 , and 9.09 per cent of the total cost. On processing one quintal of raw guava by small scale units 1.15 quintal of jelly and 1.06 quintal of Jam were recovered. After value addition the net margin received by the processors in selling 1.06 quintals of jam was Rs. 4839.25 and per kg net margin was Rs. 45.65 .

\subsubsection{Costs and Margins in the Processing of Toffee}

It can also be observed from the Table 5 that the cost incurred by the small scale units in the processing of one quintal of guava for making toffee was Rs. 7864.43, which included cost of processing, cost of raw material, transportation charges, fuel charges, loss during processing, cost of ingredients (sugar, citric acid, Glucose, skimmed milk, butter), packaging and labeling charges, miscellaneous charges and interest on working capital i.e., $2.49,6.48,0.31,1.10,0.15,16.02,0.63,10.17,11.44,7.63,34.33,0.15$ and $0.09 \%$ of the total cost. On processing one quintal of raw guava 1.35 quintals of toffee were recovered. The net margin received by the processor in selling 1.35 quintals of toffee was Rs. 6985.57 and per kg net margin was Rs. 51.75.

\subsection{Costs and Margins in the Processing of Jelly, Jam and Toffee by Large Scale Units}

\subsubsection{Costs and Margins in the Processing of Jelly}

The Table 6 revealed that the cost incurred by large scale units in the processing of one quintal of guava for making jelly was Rs.4070.38, which includes, cost of processing, cost of raw material, transportation charges, fuel charges, loss during processing, cost of ingredients (sugar, citric acid), packing and labeling charges, miscellaneous charges and interest on working capital, i.e., 5.48, 12.53, 0.32, 2.41, 0.22, 33.17, 1.28, 35.01, 0.49 and 9.10 per cent of the total cost, respectively. On processing one quintal of raw guava by large scale 1.14 quintals of jelly were recovered, and after value addition the net margin received by the processors in selling 1.14 quintals of jelly was Rs. 6189.62 and the per kilogram net margin was Rs.54.29.

Table 6. Costs and Margins in the Processing of Jelly, Jam and Toffee by Large Scale Units

\begin{tabular}{|c|c|c|c|c|c|c|c|}
\hline \multirow{2}{*}{$\begin{array}{l}\text { S. } \\
\text { No. }\end{array}$} & \multirow[b]{2}{*}{ Items } & \multicolumn{2}{|c|}{ Jelly } & \multicolumn{2}{|c|}{ Jam } & \multicolumn{2}{|c|}{ Toffee } \\
\hline & & $\begin{array}{c}\text { Amount } \\
\text { (Rs./Qtl.) }\end{array}$ & $\%$ & $\begin{array}{l}\text { Amount } \\
\text { (Rs./Qtl.) }\end{array}$ & $\%$ & $\begin{array}{l}\text { Amount } \\
\text { (Rs./Qtl.) }\end{array}$ & $\%$ \\
\hline 1 & Cost of processing & 222.90 & $(5.48)$ & 222.90 & $(6.51)$ & 222.90 & $(2.67)$ \\
\hline 2 & Cost of raw material & 510.00 & $(12.53)$ & - & & 510.00 & $(6.11)$ \\
\hline 3 & Transportation charges & 13.25 & $(0.32)$ & - & & 13.25 & $(0.16)$ \\
\hline 4 & Fuel charges/power input & 98.20 & $(2.41)$ & 98.20 & $(2.87)$ & 98.20 & $(1.18)$ \\
\hline 5 & $\begin{array}{l}\text { Loss during processing } \\
\text { Ingredient cost }\end{array}$ & 9.00 & $(0.22)$ & 9.00 & $(0.26)$ & 8.50 & $(0.10)$ \\
\hline \multirow{5}{*}{6} & $\begin{array}{l}\text { Ingredient cost } \\
\text { (a) Sugar @ } 70-75 \text { kg/q. }\end{array}$ & 1350.00 & $(33.17)$ & 1350.00 & $(39.40)$ & 1260.00 & $(15.10)$ \\
\hline & (b) Citric acid@200,gm/q. & 52.00 & $(1.28)$ & 52.00 & $(1.52)$ & 52.00 & $(0.62)$ \\
\hline & (c) Glucose @ $12 \mathrm{~kg} / \mathrm{q}$. & - & & - & & 960.00 & $(11.50)$ \\
\hline & (d) Skimmed milk@15 kg/qt & - & & - & & 900.00 & $(10.79)$ \\
\hline & (e) Butter@6kg/q. & - & & - & & 600.00 & $(7.19)$ \\
\hline 7 & Packing and labelling charges & 1425.00 & $(35.01)$ & 1362.50 & $(39.77)$ & 2940.00 & $(35.23)$ \\
\hline 8 & Miscellaneous charges & 20.00 & $(0.49)$ & 20.00 & $(0.58)$ & 21.00 & $(0.25)$ \\
\hline \multirow[t]{2}{*}{9} & Interest on working capital @10\% & 370.03 & $(9.09)$ & 311.46 & $(9.09)$ & 758.58 & $(9.09)$ \\
\hline & Total working cost & 4070.38 & $(100)$ & 3426.06 & $(100)$ & 8344.43 & $(100)$ \\
\hline 10 & $\begin{array}{l}\text { Total quantity ready from one } \\
\text { quintal Of guava }\end{array}$ & 1.14 & & 1.09 & & 1.40 & \\
\hline 11 & $\begin{array}{l}\text { Total returns from one quintal of } \\
\text { processed guava }\end{array}$ & 10260.00 & & 9673.75 & & 16800.00 & \\
\hline 12 & $\begin{array}{l}\text { Net margin from one quintal of } \\
\text { processed guava (excluding } \\
\text { marketing cost) }\end{array}$ & 6189.62 & & 6247.69 & & 8455.57 & \\
\hline 13 & Cost/kg of processed products & 35.70 & & 31.43 & & 59.60 & \\
\hline 14 & Selling price $/ \mathrm{kg}$ & 90.00 & & 88.75 & & 120.00 & \\
\hline 15 & $\begin{array}{l}\text { Net margins } / \mathrm{kg} \text { (excluding } \\
\text { marketing cost) }\end{array}$ & 54.29 & & 57.32 & & 60.40 & \\
\hline
\end{tabular}

Quantity of guava processed into jelly \& toffee [Jelly 1881.30 Qt1.], [Toffee 250.22 Qt1.]. 


\subsubsection{Cost and Margins in the processing of Jam}

Table 6 indicated that the cost incurred by the large scale units in the processing of one quintal of guava for making Jam was Rs. 3426.06, which included cost of processing, fuel charges, loss during processing, ingredient cost, (sugar, citric acid,) packing and labeling charges, miscellaneous charges and interest on working capital i.e., 6.51, $2.87,0.26,39.40,1.52,39.77,0.58$ and 9.09 per cent, respectively, of the total cost. On processing of one quintal of raw guava, 1.14 quintals of jelly and 1.09 quintals of jam were recovered. After value addition the net margin received by the large scale units in selling 1.09 quintals of jam was Rs. 6247.69 , whereas the per kg net margin was Rs. 57.32 .

\subsubsection{Costs and Margins in the Processing of Toffee}

It was observed from the Table 6 that the cost incurred by large scale units in the processing of one quintal of guava for making toffee was Rs. 8344.43 which included cost of processing, cost of raw material, transportation charges, fuel charges, loss during processing, cost of ingredients (sugar, citric acid, glucose, skimmed milk, butter), packing and labeling charges, miscellaneous charges and interest on working capital, i.e., 2.67, 6.11, 0.16, 1.18, 0.10, 15.10, $0.62,11.50,10.79,7.19,35.23,0.25$, and 9.09 per cent, respectively of the total cost. On processing of one quintal of raw guava 1.40 quintals were recorded by the large scale units. The net margin received by the processors in selling 1.40 quintals of toffee was Rs. 8455.57 and per kg net margin stood at Rs. 60.40.

\subsubsection{Price Spread, Marketing Cost and Margins in the Marketing of Raw and Processed Guava Products}

The marketing of processed products was initiated by the processors as the producers of processed products. The processors purchased the fresh guava mainly from Mundera mandi (local market in the study area) and after processing the guava fruits, they sold processed products in local market as well as in the distant markets through different middlemen. The marketing of processed product was basically commission based and the processors had to pay commission to each intermediary or they forwarded the products for some concession to make intermediaries able to earn their commissions. The main processed products of guava were jelly, jam and toffee which were manufactured by the processing units of the study area. The prices of these products hardly differed from each other, thus the analysis was performed considering the average price of these products.

In local markets the processors forwarded the guava products either through retailers or commission agents, but the cottage scale processors themselves searched out for the market of their products. They directly sold the products to consumers without the involvement of any middlemen. Commission agents were employed to capture bigger market as they sold the products by wandering door to door selling in different localities. On the other side, the retailers were able to sell the produce only to a limited number of consumers. Thus, the processors preferred to sell the produce through commission agents.

The producer's share in consumer's rupee was $0.99,2.03,106,2.17,1.71$ and 3.51 per cent in channel I, II, III, V and channel VI respectively. the marketing cost incurred by the grower was $0.84,0.89$ and 1.45 in channel II, IV and VI, respectively, while in channel I, III and V the growers did not play any role in the marketing of produce as they directly sold their standing crop to pre-harvest contractors; who takes care of the crop and markets the produce. The pre-harvest contractor received a net margin of 1.10, 1.18, and 1.90\% of the consumer's rupee, in channel I, III, and V, respectively. The marketing cost incurred by the pre-harvest contractors was found at 0.77 , 0.83 , and $1.34 \%$ of the consumer's rupee in channel I, III and V, respectively.

The Table 7 indicated that processors' share was higher as compared to that of all the intermediaries involved in the marketing of processed guava products, because the processors added value to the product. After the value addition the net amount received by the processor was found (average of Jam, Jelly and Toffee) as Rs. 5127.60 in channel I and II, i.e., $28.90 \%$ of the consumer's rupee. The net amount received by the processor in channel III and IV was found to be Rs. 4324.80 which was $25.97 \%$ of the consumer's rupee. In channels V \& VI the processor's share was found as Rs. 4420.93 , which was $42.94 \%$ of the consumer's rupee. The total marketing cost incurred by the processors was found at Rs. 7116.98 in channels I and II, i.e., $40.11 \%$ of the consumer's rupee. Marketing cost incurred by the processors in channel III and IV was found as Rs. 7258.53 i.e., $43.58 \%$ of the consumer's rupee. The cost incurred by the processors in channel V and VI was found as Rs. 5873.44 which was $57.05 \%$ of the consumer's rupee.

As mentioned earlier that the processors did sell their produce through commission agents. The commission agents would sell the produce on commission basis, the commission ranged from $15-22 \%$. 
Table 7. Price spread, marketing costs and marketing margins, channel wise for raw and processed guava (Quantity in quintals/value in rupees)

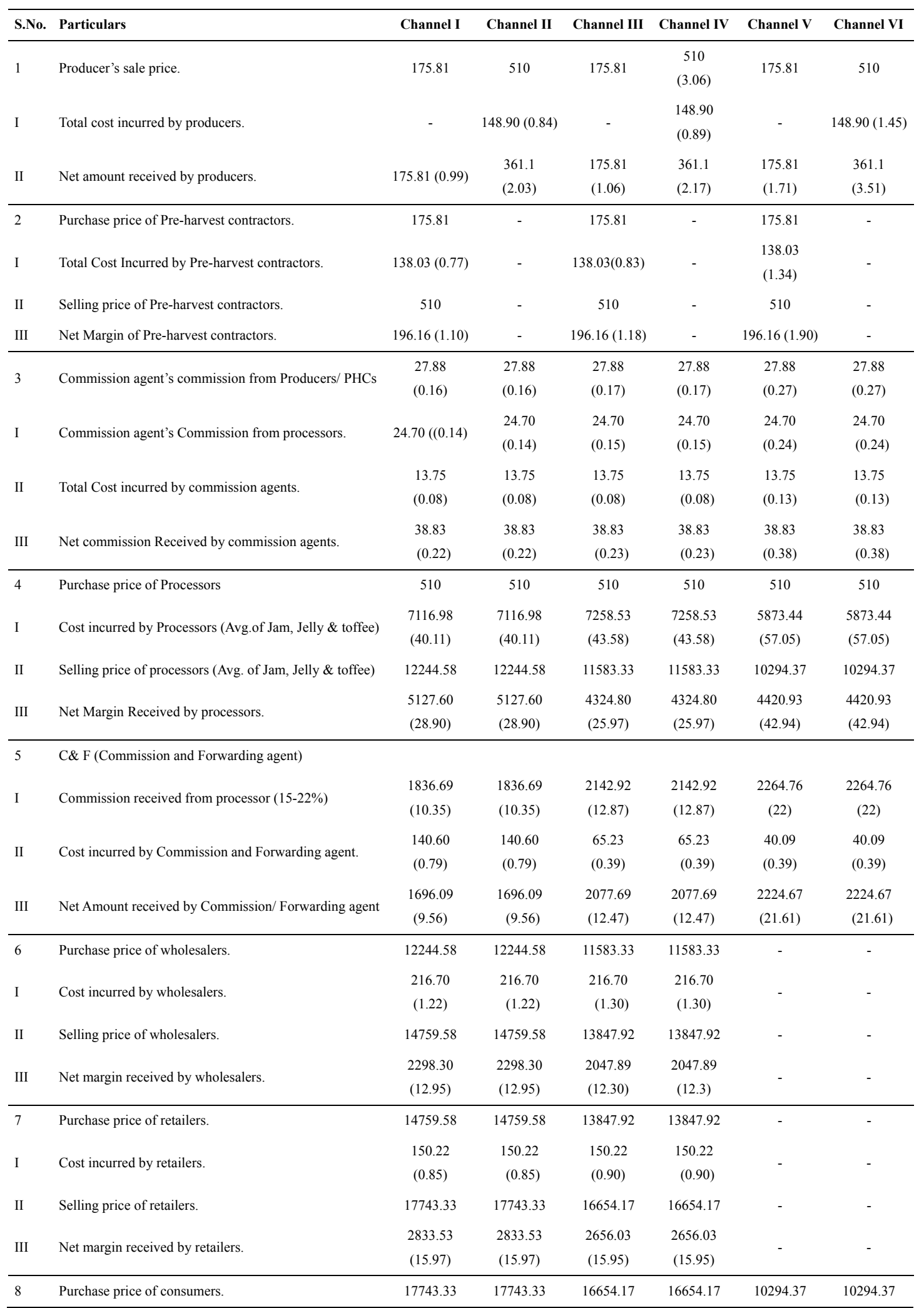

* commission to C \& F @22 \%( cottage scale).

(Figures in parentheses indicate percentage to total).

* commission to C \& F@18.50\%( small scale).

* commission to C \& F @15 \%( large scale). 
The net share received by the commission and forwarding agent was found as Rs. 1696.09 in channels I and II, i.e., $9.56 \%$ of the consumer's rupee. The net amount received by commission and forwarding agent in channel III and IV was Rs. 2077.69 , i.e., $12.47 \%$ of the consumer's rupee. In channels V and VI the net share of the commission and forwarding agent was found to be Rs. 2224.67 which is $21.61 \%$ of the consumer's rupee. The cost incurred by the commission and forwarding agent was found as Rs. 140.60 in channel I and II, Rs. 65.23 in channel III and IV and Rs. 40.09 in channel V and IV, which was estimated as $0.79 \%$ in channel I and II, $0.39 \%$ in channel III , IV, V and VI of the consumer's rupee. The Table 7 also indicated that wholesaler received a net margin of Rs. 2298.30 in channels I and II, i.e., $12.95 \%$ of the consumer's rupee and Rs. 2047.89 in channels III and IV which was $12.30 \%$ of the consumer's rupee. The cost incurred by the wholesaler was found as Rs. 216.70 in channels I and II, i.e., $1.22 \%$ of the consumer's rupee and Rs. 216.70 in channel III and IV which was $1.30 \%$ of the consumer's rupee. In channels V and VI, the wholesaler did not exist.

It was also observed from the Table 5.30 that net amount received by the retailers was Rs. 2833.53 in channels I and II, which was $15.97 \%$ of the consumer's rupee and the net amount received by the retailer in channels III and IV was Rs. 2656.03 , i.e., $15.95 \%$ of the consumer's rupee. The total cost incurred by the retailer was found at Rs. 150.22 in channels I, II, III and IV, which was 0.85 per cent of the consumer's rupee in channel I and II and 0.90 per cent in channels III and IV.

\subsubsection{Marketing Efficiency in Different Channels of Processed Guava Products}

It may be observed from the Table 8 that channel VI was found to be most efficient channel, with marketing efficiency of 0.73 , followed by channel V, I, II, III and IV with marketing efficiencies of $0.71,0.38,0.380 .33$ and 0.33 , respectively.

Table 8. Marketing efficiency of different marketing channels of processed guava products

\begin{tabular}{|c|c|c|c|c|c|c|c|c|}
\hline $\begin{array}{l}\text { S. } \\
\text { No. }\end{array}$ & Particulars & Unit & $\begin{array}{c}\text { Channel } \\
\text { I }\end{array}$ & $\begin{array}{c}\text { Channel } \\
\text { II }\end{array}$ & $\begin{array}{c}\text { Channel } \\
\text { III }\end{array}$ & $\begin{array}{c}\text { Channel } \\
\text { IV }\end{array}$ & $\begin{array}{c}\text { Channel } \\
\text { V }\end{array}$ & $\begin{array}{c}\text { Channel } \\
\text { VI }\end{array}$ \\
\hline 1 & Total marketing cost (MC) & Quintal & 7621.93 & 7632.80 & 7763.48 & 7774.35 & 6011.47 & 6022.34 \\
\hline 2 & $\begin{array}{l}\text { Total net margins of } \\
\text { intermediaries }(\mathrm{MM})\end{array}$ & Quintal & 5973.93 & 5777.77 & 5455.84 & 5259.68 & 196.16 & - \\
\hline 3 & $\begin{array}{l}\text { Net price received by the } \\
\text { Processor }(\mathrm{PP})\end{array}$ & Quintal & 5127.60 & 5127.60 & 4324.80 & 4324.80 & 4420.93 & 4420.93 \\
\hline \multirow[t]{2}{*}{4} & \multicolumn{8}{|l|}{ Index of marketing efficiency } \\
\hline & $\begin{array}{l}\text { Acharya's method (MME): } \\
3 /(1+2)\end{array}$ & Ratio & 0.38 & 0.38 & 0.33 & 0.33 & 0.71 & 0.73 \\
\hline
\end{tabular}

3.6.6 Costs and Margins in the Processing of Jelly and Jam by Cottage Scale

The Table 9 indicates that the total quantity of Jam and Jelly produced by the cottage scale was 96.89 quintals i.e., Jelly 50.22 quintals and Jam 46.67 quintals. The total cost in the preparation of Jam and Jelly was Rs. 320766.07. After the sale of these two products the net receipt was Rs. 594298.93 respectively. The benefit cost ratio was found as 2.74 in case of jelly, 2.99 in case of Jam and for the firm as whole, it was 2.85.

3.6.7 Costs and Margins in the Processing of Jelly, Jam and Toffee by Small Scale Units

It is observed from the Table 10 that the total quantity of jelly, jam and toffee produced by the small scale units was found to be 237.37 quintals, i.e., in jelly- 100.19 quintals, Jam- 92.35 quintals and toffee- 44.83 quintals. The total cost in the preparation of jelly, jam and toffee was found as Rs. 912947.80 . After the sale of these products the net receipt was Rs. 1109938.45. The returns per rupee of investment were found as 2.28 in jelly, 2.43 in jam and 1.89 in toffee and in aggregate it was found at 2.22.

\subsubsection{Costs and Margins in the Processing of Jelly, Jam and Toffee by Large Scale Units}

The Table 11 reveals that the total quantity of jam, jelly, and toffee produced by large scale units was 4545.61 quintals, i.e., 2144.68 quintals of jelly, 2050.62 quintals of jam and 350.31 quintals of toffee. The total cost in the preparation of jelly, jam and toffee was found as Rs. 16189453.86. After the sale of these products the net receipt 
was Rs. 25515638.64. The returns per rupee of investment were found to be 2.52 in jelly, 2.82 in jam and 2.01 in toffee, and in aggregate it was found as 2.58 .

Table 9. Total costs and margins in the processing of jelly, jam and toffee by small, large and cottage scale units

\begin{tabular}{|c|c|c|c|c|c|}
\hline S. No. & Particulars & Jelly & Jam & Toffee & Firm as whole \\
\hline A & Small scale units & & & & \\
\hline a. & Total quantity produced (quintals) & 100.19 & 92.35 & 44.83 & 237.37 \\
\hline b. & Total cost & 357678.30 & 294134.75 & 261134.75 & 912947.80 \\
\hline c. & Gross income & 814043.75 & 715712.50 & 493130.00 & 2022886.25 \\
\hline d. & Net income & 456365.45 & 421577.75 & 231995.25 & 1109938.45 \\
\hline e. & Benefit cost ratio & $1: 2.28$ & $1: 2.43$ & $1: 1.89$ & $1: 2.22$ \\
\hline B & Large scale units & & & & \\
\hline a. & Total quantity produced (quintals) & 2144.68 & 2050.62 & 350.31 & 4545.61 \\
\hline b. & Total cost & 7656507.60 & 6445098.66 & 2087847.60 & 16189453.86 \\
\hline c. & Gross income & 19302120.00 & 18199252.50 & 4203720.00 & 41705092.50 \\
\hline d. & Net income & 11645612.4 & 11754153.84 & 2115872.40 & 25515638.64 \\
\hline e. & Benefit cost ratio & $1: 2.52$ & $1: 2.82$ & $1: 2.01$ & $1: 2.58$ \\
\hline $\mathbf{C}$ & Cottage scale units & & & & \\
\hline a. & Total quantity produced (quintals) & 50.22 & 46.67 & - & 96.89 \\
\hline b. & Total cost & 176322.42 & 144443.65 & - & 320766.07 \\
\hline c. & Gross income & 483367.50 & 431697.50 & - & 915065.00 \\
\hline $\mathrm{d}$. & Net income & 307045.08 & 287253.85 & - & 594298.93 \\
\hline e. & Benefit cost ratio & $1: 2.74$ & $1: 2.99$ & - & $1: 2.85$ \\
\hline
\end{tabular}

\subsubsection{Constraints Encountered by Guava Processors}

In the present study, it was observed that the entrepreneurs did not face any critical problem. Nevertheless, some technical constraints and the problems related to marketing of processed products were faced, which are discussed below:

1). Allahabad is known for its best guava; even then it fails to fulfil the requirements of processors. Fresh, matured, tight, seedless guava is preferred for the processing, but due to the lack of proper grading or proper knowledge about the processing of guava among the orchardists, processors were bound to purchase the mixed variety of guava that resulted in the decrease in quality of processed products.

2). The non-availability of skilled labour was found as one of the problems faced by the entrepreneurs. The labour was in abundant but they were required to be trained first before getting involved in the manufacturing of the products. All the cottage scale units of the study area reported the problem of skilled labour. Cottage scale units employed the labourers only on the basis of the demand of products in the market. If there was higher demand for processed products, surplus labour was employed. Hence, the entrepreneurs of this category faced this problem during a particular period of the season, as they did not get skilled labourers at right time. Therefore they had to train the labourers first and then to start their production. The small and large scale units generally employed the permanent labourers. But if the demand for processed guava products was higher in the markets only then they had to employ the temporary labourers.

3). Another problem reported by the processors of the study area was lack of capital inputs or financial constraints, However only cottage scale units faced this problem.

4). Setting of processed products, viz., Jelly, Jam and toffee, is a technical problem faced by cottage and small scale units. It may be either due to the lack of technical knowledge or due to some imbalanced ingredients used. This problem may cause loss to guava, because on the one hand they could not increase the price of their finished products because of competition in the markets, and on the other hand, they were bound to manufacture good quality products. However, the large scale units did not report this technical problem.

5). It is a well known fact that the processed products rarely figure in the menu of Indians. Processed products are not preferred in the regular diet. This is the main reason that only two per cent of the total fruits and vegetables are being processed in the country. The main processed products of guava are jelly and 
jam which are being marketed in Allahabad as well as transported to other places. However there is lack of demand for these products as reported by the processors of the study area.

6). High degree of competition was reported by most of the entrepreneurs as they had to search for the market of their processed products. The products of cottage scale units were sold at comparatively lower rates and marketed by the processors themselves. But all the cottage scale processors had their fixed markets, thus the degree of competition was very low in this category. But in case where the products were sold through retail shops, higher degree of competition was reported. In selling the products outside Allahabad district, the small category processors had to compete with the processor of distant markets. So the processors of study area searched for those markets where the number of processors was less or where the availability of raw material was a constraint.

\section{Conclusions and Policy Implications}

Processing of Guava is economically feasible and hence needs to be encouraged. It provides wide scope for employment opportunities to the skilled and unskilled labourers in the rural areas, besides it has potential to earn valuable foreign exchange to the country. There is wide scope for processing industry, as production is higher than the demand particularly during the peak period. Though a variety of guava products can be prepared, but a very little portion of the surplus production of guava is utilized for processing and value addition. To avoid the glut during peak period, processing industry can prove very successful in better marketing, and boosting the interest of the guava growers towards this popular fruit for their overall prosperity. The following suggestions can prove helpful to the farming community and processing industry.

1). The Processors faced problems like unassured market for their output and high cost of fuel. In this regard the government can intervene and make arrangements for exports. Technocrats and scientists can develop energy efficient and superior technology for processing.

2). During the course of study it was found that no encouragement / importance were given by the concerned departments in the processing and marketing of Guava. Hence, the concerned development department and financial institutions must popularize the processing of Guava in the study area by providing latest technical know-how, finance and other infrastructural facilities.

3). Guava is highly nutritive and cheap; by judicious management of the guava fruits, lots of the nutritive food products can be made available to the people of the country and abroad along with wide employment and business opportunities.

\section{References}

Francis, J. A. (1999). Profiles of fruit processing companies in the Caribbean Region. Tropical fruits Newsletter, 31, 10-13.

Joshi, M. G., Waker, S. S., Veerkar, P. D., \& Pawar, A. G. (1999). Comparative economics of processing Alphanso mango into pulp in South Konkan Region. Bihar Journal of Agricultural Marketing, 2, 190-194.

Malleswari, M. N. (1996). Mango processing in Andhra Pradesh, Potential infrastructure and constraints. Indian Journal of Agricultural Marketing, 10(2), 18-27.

Naphade, S. A., \& Tingre, A. S. (2008). Economics of production and marketing of guava in Buldhana district of Maharashtra. Indian Journal of Agricultural Marketing, 22(2), 32-41.

Reddy, D. M. G., Gowda, M. V. S., Changoppa, P. G., \& Achoth, L. (1997). Determining the number and location of fruit processing plants in Karnataka. Tropical Agricultural Research, 9, 126-136.

Wijeratnam, R. S. W., Herregods, M., Nicoli, B., Jager, A. D., \& Roy, S. K. (2000). Identification of problems in processing of underutilized fruits of the tropics and their solutions. Acta Horticulture, 518, 237-240. 